\title{
Character-based 4C Learning Model to Improving Students' Metacognitive Abilities: A Develop Phase of Research \& Development
}

\author{
Abdul Wahid*, Muhammad Arifin Ahmad, Pattaufi \\ Department of Education, Makassar State University, South Sulawesi, Indonesia
}

Received January 13, 2021; Revised February 18, 2021; Accepted March 22, 2021

\begin{abstract}
Cite This Paper in the following Citation Styles
(a): [1] Abdul Wahid, Muhammad Arifin Ahmad, Pattaufi, "Character-based 4C Learning Model to Improving Students' Metacognitive Abilities: A Develop Phase of Research \& Development," Universal Journal of Educational Research, Vol. 9, No. 3, pp. 650 - 659, 2021. DOI: 10.13189/ujer.2021.090324.
\end{abstract}

(b): Abdul Wahid, Muhammad Arifin Ahmad, Pattaufi (2021). Character-based 4C Learning Model to Improving Students' Metacognitive Abilities: A Develop Phase of Research \& Development. Universal Journal of Educational Research, 9(3), 650 - 659. DOI: 10.13189/ujer.2021.090324.

Copyright $\bigcirc 2021$ by authors, all rights reserved. Authors agree that this article remains permanently open access under the terms of the Creative Commons Attribution License 4.0 International License

\begin{abstract}
This research aims to determine the level of validity, practicality, and effectiveness (develop phase) development of character-based 4C learning models to improve students' metacognitive abilities. This research focuses on the develop phase of the 4D theory (Define, Design, Develop and Disseminate) by Thiagarajan, Semmel, \& Semmel (1974). The develop phase consists of validity testing by experts, practicality testing by lecturers, and effectiveness testing by students. The subjects of this research were 16 students and 2 lecturers of the Primary School Teacher Education Research Program (PGSD) STKIP Andi Matappa, Pangkep Regency. In addition, two validators were also selected as participants to assess the validity of this research product. The data collection techniques used was validation sheet, questionnaire, and tests. The collected data were analyzed using a quantitative approach with the help of SPSS 23.00. The results showed that the research products in the form of model books and character-based 4C learning tools were declared valid, practical, and effective and could be used by lecturers to teach Pancasila and Citizenship Education courses.
\end{abstract}

Keywords Character, 4C Learning Model, Metacognitive, Validity, Practicality, Effectiveness

\section{Introduction}

The learning carried out by lecturers in the observations of researchers emphasized more on aspects of understanding, while aspects of application, analysis, synthesis, and even evaluation were only a small part of the learning that was carried out [1]. This causes students to be less trained to develop their rational powers in solving problems and applying the concepts that have been learned in real life. Students are less able to express their arguments so that students' metacognitive abilities cannot develop properly [2]. Therefore, in the lecture process, it must have a learning model in the achievement of the process and learning outcomes, efficient use of time, energy, and aimed at achieving predetermined goals. One of the steps to have that learning model, lecturers must master teaching techniques and teaching methods [3], [4]. Lecturers are required to master various kinds of learning models in accordance with the characteristics of the material and students. Through observation and discussion with several campus lecturers, this is because the presentation and learning methods that have been applied so far are not varied and the learning models used have not been able to develop students' metacognitive abilities [5]. 
The 4C learning model (Communication, Collaboration, Critical Thinking and Problem Solving and Creativity and Innovation) has an important role in modern education and can improve students' metacognitive [6]. Because, currently students who will become the nation's next generation will face more complex problems in the future. It is they, the nation's next generation, who will rule the world [7]. Learning 4C (Communication, Collaboration, Critical Thinking and Problem Solving and Creativity and Innovation) aims to create graduates who are able to compete globally, especially because later as a workforce we will be more encouraged to technology. Therefore, it is important to introduce students to the $4 \mathrm{C}$ learning model [8].

The $4 \mathrm{C}$ learning model aims to improve the quality of education in order to answer challenges, both internal challenges and external challenges. 4C learning (Communication, Collaboration, Critical Thinking and Problem Solving and Creativity and Innovation) does not mean only the practical strengthening of education in $4 \mathrm{C}$ fields separately, but rather develops an educational approach that integrates the four fields, by focusing the educational process on solving problems in daily life and professional life [9]. The purpose of the $4 \mathrm{C}$ learning model in the world of education is in line with the demands of $21^{\text {st }}$ century education, namely that students have more valuable life skills which are marked by skills of faith and caution, have a character as thinkers, are proficient in using technology and information, skilled in interactive communication with smart and humble, and able to develop plans, break results of achievement, are skilled at working on work tools, and improve skills in line with technological developments [9], [10].

The application of the $4 \mathrm{C}$ learning model is accompanied by active learning, collaboration, creativity, innovation and problem solving so that students will be able to think critically, analytically, and focus on solutions [11]. In the 4C learning model education there are still deficiencies that are encountered when learning is being tried to be applied. However, even so in real life the application of the $4 \mathrm{C}$ model approach greatly benefits the development of science and technology, as well as developments relating to human social affairs itself [12]. Thing this is what requires the authors to develop a character-based $4 \mathrm{C}$ learning model to improve the metacognitive abilities of STKIP students Andi Matappa Pangkep to create active, collaborative, creative, innovative, and applicable learning based on solution to problem [13], [14].

\section{Literature Review}

\subsection{Learning Model}

To understand the definition of a learning model, it is necessary to briefly review what is meant by modeling and learning separately. In simple terms, the model is defined as a reference of variety, example, miniature, or form that is arranged in an orderly, proportional, and systematic manner.A model is a design that is made specifically using systematic steps to be applied in an activity. In addition, a model is often called a design that is designed in such a way to then be applied and implemented [15].

On the other hand, learning is the nature and needs of every human being. Various kinds of learning models have been applied or are being tested to achieve the expected learning goals [16], [17]. Learning is an activity that is carried out by a person deliberately in a conscious state to obtain a new concept, understanding, or knowledge so as to enable a relative change in behavior [18]. Meanwhile, learning is an effort to organize an environment to create learning conditions for students [19].

In the context of learning, this model is a specific approach used in the learning process [20]. The learning model is also defined as a conceptual framework that describes a flow or procedure systematically in managing and organizing learning activities that serve as a guide for teachers [21]. A similar statement was also made by Pateliya [22] which calls the learning model a learning concept related to guidelines and references in designing learning activities. Joyce, Weil, \& Calhoun [13]defines the learning model as a way to help learners to obtain information, ideas, skills, values and ways of thinking and improve the ability of learners to learn. In addition, the learning model can also be interpreted as a learning model containing certain strategies in facilitating learning for students to be able to understand learning material [23], [24].

In general, a learning model has several aspects in it. According to Joyce et al. [13] There are five aspects in a learning model, namely: (a) syntax or operational steps for learning, (b) social systems or the atmosphere and norms that apply in learning, (c) principles of reaction which describe how teachers should encourage and respond to students, (d) support system is all means, materials, or learning environment that supports learning, and (e) instructional and nurturant effects that are obtained directly based on the objectives to be achieved and the results of the accompanying effects or nurturant effects.

\subsection{The Four C (4C)}

Along with the presence of the industrial revolution 4.0 and society 5.0, the competencies that college graduates must master are increasingly diverse. The skills required by university graduates are not only limited to the ability to read, write, count, and other subjects but also extend to competencies related to the 21 st century at present. World Economic Forum [25]describes several competencies or that must be mastered by college graduates, namely foundational literacies, competencies, and character skills. In the competencies group, WEF divides into several sub-competencies, namely: (a) critical thinking/problem-solving, (b) creativity, (c) 
communication skills, and (d) collaboration known as the $4 \mathrm{C}$ or super skills.

\section{a). Critical Thinking or Problem Solving}

In general, critical thinking is a type of ability to see events, conditions, or thoughts from a careful point of view and make comments, decisions, and research the reliability and validity of knowledge based on standards of logic and thinking. According to Sanavi \& Tarighat [26] the definition of critical thinking is divided into three parts, namely philosophical, psychological, and educational approaches. Definitions based on a philosophical approach focus on the hypotheses of critical thinkers, listing the qualities and characteristics of critical thinkers, and not on the behavior or actions of critical thinkers. The psychological approach is focused on how people think rather than how they think under circumstances. Whereas an education-based approach, critical thinking is defined as the capacity to go beyond the information provided, adopt a critical stance, evaluate, have metacognitive concerns, and the capacity to solve problems.

There are several characteristics of critical thinking according to Nickerson, quoted by Turabik \& Gun [27], namely: (a) using evidence objectively and skillfully, (b) being able to organize thoughts, expressing briefly, abstractly and consistently, (c) distinguishing which assumptions are reasonable and which are not, (d) delaying making decisions because lack of evidence, (e) understanding the difference between rational and reason, (f) trying to predict the likelihood of outcome or alternative action, (g) seeing vague similarities, (h) learning independently, (i) applying problem-solving techniques, and (j) use clear arguments.

\section{b). Creativity}

Creativity is defined as a multidimensional construction consisting of cognitive variables, personal characteristics, family, educational aspects, and social and cultural elements [28]. Creativity is related to mental processes related to human cognitive processes [29]. In addition, creative thinking is also classified as a high-level ability to create something new which is a skill that must be developed in the $21^{\text {st }}$ century [30].

During development, the definition of creativity changes. Bialik \& Fadel [31] mentioned that creativity is an integration of various skills such as scientific thinking skills, entrepreneurship, design thinking, and mathematics. In a humanistic perspective, creative people have the awareness and ability to deal with crises in transformative ways. In other words, creative people are people who are in the process of achieving self-actualization and developing characteristics related to their mental health. Creativity has several characteristics, namely:(a) imagination, (b) openness to experience, (c) curiosity, (d) intuition, (e) idea search, (f) tolerance for ambiguity, (g) independence, (h) innovation, (i) insight, (j) internal \&external openness, (k) illumination or insight, (l) problem discovery, and (m) image [32].

\section{c). Communication}

Communication is defined as a process of exchanging information from one person to another/other group using symbols either through verbal or non-verbal methods. In addition, communication is also related to the exchange of ideas, opinions and information with specific objects [33]. In line with the opinion above, communication is also defined as the process of transmitting meaning from one person to another, both verbally and non-verbally. The communication in question is inseparable from several components in it, namely context, sender, receiver, and the message itself [34].

In the context of classroom learning, educators must be able to provide strategies and methods in increasing the effectiveness of students' communication skills. In developing these abilities, there are various things that must get the attention of educators associated with the current digital era. Some of these points are: (a) communicating with digital media to support individual and group learning, (b) sharing information effectively and efficiently using appropriate digital media, and (c) communicating thoughts and ideas clearly and effectively to different audiences by using a variety of formats and media.

\section{d). Collaboration}

The term collaboration does not only mean working together in one group but also includes other aspects. Basically, collaboration is a joint effort in a community to socialize and control ego or personal emotions. Collaboration is defined as a small group consisting of two or more people who: (a) interact with each other, (b) depend on each other, (c) define them as belonging to the group, (d) share norms and rules, (e) influence each other, (f) mutual respect, and (g) achieve the same goal [35].

Collaboration is a key element of student success in today's global and technological society [36]. Thus, teachers need to show what it feels like to work with mutual respect in diverse groups. This means that collaboration can be achieved by embracing diversity and mutual tolerance between group members. Collaboration is an activity that occurs when two or more people work together to achieve the goals that have been set together. In order to collaborate well, students must learn to: (a) work effectively with members of different groups/groups, including people from different cultural backgrounds, (b) be flexible and seek to compromise with other members in achieving goals, and (c) showing shared responsibility in achieving goals.

\subsection{Character Based 4C Learning Model}

The character-based $4 \mathrm{C}$ learning model is a combination of the $4 \mathrm{C}$ and character learning model. This learning 
model is learning that pays attention to the active involvement of students, it can result in students feeling valued, moreover all the ideas they convey are also appreciated by both group members and lecturers. Students openly express ideas or opinions about their problems and how to solve them. Students will feel happy to be in groups to discuss about solving the problems they face. If you have difficulties, they are resolved together. The syntax for the character-based 4C learning model is as follows: (a) orientation, (b) skimming, (c) mind mapping; (d) questioning; (e) exploring; (f) writing; (g) communicating; and (h) evaluation.

\subsection{Metacognitive}

Metacognitive is a person's awareness of how he learns, the ability to assess the difficulty of a problem, the ability to observe his level of understanding, the ability to use various information to achieve goals and the ability to assess his own willingness to learn [37], [38]. Metacognitive strategies refer to ways to raise awareness about the processes of thinking and learning that prevail so that when this awareness is manifested. Therefore, a person can guard his thoughts by designing, monitoring and assessing what he learns [39].

Learning using a metacognitive approach does require an active role from lecturers and students. Lecturers as a determinant of how the learning process in their class will run provides directions to their students about how to follow the learning process. According to Hartman quoted by Nurjanah [19] that in metacognitive teaching, it is necessary for the role of an educator to discuss and explain the characteristics of thinking such as: (a) discussing the importance of metacognitive knowledge and regulation; (b) describes the skills or strategies involved in metacognitive; (c) provide models and examples for students in implementing metacognitive strategies; (d) explain when, why and how to use the strategy, while emphasizing flexibility in choosing the appropriate strategy; (e) help students recognize the implicit processes they use; (f) involve students in speaking or reflecting on implicit processes, and; ( $\mathrm{g}$ ) provide feedback.

\section{Materials \& Method}

\subsection{Research Method}

This research is a research and development research that refers to the 4D model (Define, Design, Develop, \& Disseminate) proposed by Thiagarajan, Semmmel, \& Semmel [40]. This research focuses on the develop phase which consists of: (a) validity test, (b) practicality test, and (c) effectiveness test. The validity test is aimed at two validators who assess the level of validity of the product developed while the practicality test is a test based on the practitioner's / lecturer assessment [41], [42]. Finally, the effectiveness test is a product trial through questionnaires and learning tests aimed at students.

\subsection{Research Site \& Participants}

The process of development and limited dissemination is planned to be carried out at the STKIP Andi Matappa Primary School Teacher Education Research Program (PGSD), Pangkep Regency. Participants in this research can be divided into three groups, namely: (a) a group of 16 students, (b) a group of 2 lecturers, and (c) a group of 2 experts/validators.

\subsection{Data Collection}

\section{a). Validation sheets}

This validation sheet is intended for validators to measure the level of validity of the products being developed. The validation sheets used in this research consisted of the Semester Learning Plan Validation Sheet (RPS), Lecture Unit (SAP), Student Worksheet validation sheets (LKM), Textbook Validation Sheets, Learning Process validation sheets, and Learning Outcomes Test validation sheets (THB).

\section{b). Lecturer response questionnaire}

In testing the level of practicality, researchers need to use a lecturer response questionnaire to provide justification and assessment of the $4 \mathrm{C}$ learning model. The lecturer response questionnaire consists of four aspects which include: (a) learning device components, (b) presentation feasibility aspects, (c) language feasibility aspects, and (d) learning assessment aspects. This questionnaire consists of 16 statements in the form of a Likert scale with the highest score of 4 and the lowest of 1 .

\section{c). Student response questionnaire}

Another instrument used to measure the practicality of the $4 \mathrm{C}$ learning model is a student response questionnaire. This questionnaire consists of four aspects of assessment, namely: (a) components of learning tools, (b) novelty in components, (c) understanding of the contents of model books and textbooks, and (d) metacognitive abilities. Unlike the lecturer response questionnaire, this questionnaire consists of 23 statements in the form of a Likert scale.

\section{d). Learning outcome test}

Giving learning outcomes tests in accordance with the indicators and objectives developed by the researcher. The test is used to measure or determine the contribution of the 4C model development to see the increase in metacognitive abilities through Pancasila and Citizenship Education (Civics) courses. Tests made before they are referred to students have been tested for validation first. The 10 item essay test was used before (pretest) and after (posttest) 
treatment that measured several components, namely: (a) objectives, (b) keyword problems, (c) addressing problems, (d) point of view, (e) information, (f) concepts, (g) interpretation, (h) alternative solutions to problems, (i) inferences, and (j) implications or consequences.

\subsection{Data Analysis}

\section{a). Analysis for the level of validity}

The data analysis techniques for validating learning devices include Semester Learning Plans, model books, teaching materials, lecturer response questionnaires, and learning outcome text instruments. The data obtained were analyzed by the average score for each aspect and then the overall average score is calculated using the following formula [43].

Average total $\operatorname{score}(\bar{X})=\frac{\sum \bar{A}_{i}}{n}$

Information:

$$
\begin{aligned}
& (\bar{X})=\text { total mean } \\
& \bar{A}_{i}=\text { average of the ith aspect } \\
& n=\text { many aspects }
\end{aligned}
$$

Table 1. Category of assessment level of validity [44], [45].

\begin{tabular}{cc}
\hline Score Interrval & Assessment Category \\
\hline $3.6 \leq \mathrm{p} \leq 4$ & Very Valid \\
\hline $2.6 \leq \mathrm{p} \leq 3.5$ & Valid \\
\hline $1.6 \leq \mathrm{p} \leq 2.5$ & Invalid \\
\hline
\end{tabular}

\section{b). Data analysis for the level of practicality}

The data from the lecturer and student response questionnaires were separately analyzed by determining the average score of the responses then matched with a predetermined score interval table using the following formula.

$$
\text { Average response }(\mathrm{RR})=\frac{\text { Totalaverageofallaspects }}{\text { Numberofaspects }}
$$

Table 2. Intervals for the practicality of the lecturers' responses [44].

\begin{tabular}{|c|c|c|}
\hline No. & Score & Criteria \\
\hline 1. & $3.6 \leq \mathrm{M} \leq 4.0$ & Very practical \\
\hline 2. & $2.6 \leq \mathrm{M} \leq 3.5$ & Pretty practical \\
\hline 3. & $1.6 \leq \mathrm{M} \leq 2.5$ & Less practical \\
\hline 4. & $1.0 \leq \mathrm{M}<1.5$ & It's not practical \\
\hline
\end{tabular}

\section{c). Analyze data for effectiveness}

Technical analysis of the improvement of students' metacognitive abilities was carried out quantitatively. Analysis of students' metacognitive abilities measures the effectiveness of learning devices. The calculations were carried out in Microsoft Excel and SPSS 20. The metacognitive abilities of students after being given treatment using the $4 \mathrm{C}$ model were carried out inferential statistical analysis with SPSS 20.

\section{Results}

As previously described, this research aims to investigate the develop phase of research and development using 4D theory. This develop phase consists of three main parts, namely: (1) validation test, (2) practicality test, and (3) effectiveness test. This means that the product developed in the form of a character-based 4C learning model has been designed and continued for trials in the development phase. The test results in the three sections can be seen in the following description.

\section{1) The validity of the product developed \\ a. Learning Model Book}

The validator's assessment of the character-based $4 \mathrm{C}$ learning model book in improving the metacognitive abilities of PGSD students is conducted to determine the level of its validity. The average value of each aspect of the assessment in the character-based $4 \mathrm{C}$ learning model book

\begin{tabular}{|c|c|c|c|c|}
\hline No. & Assessment Aspects & $\overline{\mathbf{x}}$ & (Ai) & Information \\
\hline 1. & $\begin{array}{l}\text { Development } \\
\text { foundation }\end{array}$ & 3.54 & 3,6 & Valid \\
\hline 2. & Language & 3.54 & 3,6 & Valid \\
\hline 3. & $\begin{array}{l}\text { The suitability of the } \\
\text { material with the } \\
\text { character-based } 4 \mathrm{Cs} \\
\text { learning model }\end{array}$ & 3.54 & 3,6 & Valid \\
\hline 4. & $\begin{array}{l}\text { Character-based } \\
\text { planning of the } 4 \mathrm{Cs} \\
\text { learning model }\end{array}$ & 3.54 & 3.5 & Valid \\
\hline 5. & $\begin{array}{l}\text { Implementation of } \\
\text { the character-based } \\
\text { 4Cs learning model }\end{array}$ & 3.54 & 3.5 & Valid \\
\hline 6. & $\begin{array}{c}\text { Character-based 4Cs } \\
\text { learning model } \\
\text { assessment }\end{array}$ & 3.54 & 3.5 & Valid \\
\hline
\end{tabular}
can be seen in the following table:

Table 3. Average result of character-based $4 \mathrm{Cs}$ learning model book validation

Based on the results of the analysis shown in table 3 above, it can be explained that the total validity value of the character-based 4C learning model book is obtained $=3.54$. Based on the existing validity criteria, the average value is included in the valid category because it is at $2.6 \leq \mathrm{p}<3.5$. As for the basic aspects of development, aspects of language and appropriateness of the material with the character-based 4C learning model, the components of the learning model book assessment have the highest validity criteria, namely $3.6 . \bar{x}$

\section{b. Semester Learning Plans \& Lecture Units}

Besides learning book model, Semester Learning Plans was also validated to see its validity. The average value of 
each aspect of the assessment on the components of the semester learning plan and lecture units can be presented in table 4 the following:

Table 4. Average validation results semester lesson plans and lecture units

\begin{tabular}{ccccc}
\hline No. & $\begin{array}{c}\text { Assessment } \\
\text { Aspects }\end{array}$ & $\overline{\mathbf{x}}$ & (Ai) & Information \\
\hline 1. & Format Components & 3.67 & 3.8 & Very Valid \\
\hline 2. & $\begin{array}{c}\text { Content } \\
\text { Components }\end{array}$ & 3.67 & 3.6 & Very Valid \\
\hline 3. & $\begin{array}{c}\text { Language } \\
\text { Component }\end{array}$ & 3.67 & 3.7 & Very Valid \\
\hline
\end{tabular}

Based on the results of the analysis shown in table 4 , it shows that the total validity average value of the Semester Learning Plan and Lecture Units in developing students' metacognitive abilities through the character-based $4 \mathrm{C}$ learning model is 3.67. Based on the existing validity criteria, this value is included in the very valid category because it is in the validity criteria3. $6 \leq \mathrm{p} \leq 4$. Meanwhile, all assessment components in the Semester Learning Plan and Lecture Units, the format aspect has a high validity criterion, namely 3.8. Besides providing an assessment, the validator also provides suggestions and comments for revisions to the Semester Learning Plan and Lecture Units that are being developed.

\section{c. Learning Outcome Text Instruments}

The next product of this research was validated is learning outcome text instruments. The average value of each aspect of the assessment on this learning tool can be seen in table 5 as follows:

Table 5.Average results of the text instrument validation learning outcomes

\begin{tabular}{ccccc}
\hline No. & $\begin{array}{c}\text { Assessment } \\
\text { Aspects }\end{array}$ & $\overline{\mathbf{x}}$ & (Ai) & Information \\
\hline 1. & Theory & 3.75 & 3.5 & Very Valid \\
\hline 2. & Presentation Format & 3.75 & 3.8 & Very Valid \\
\hline 3. & Language & 3.75 & 3.8 & Very Valid \\
\hline 4. & Time & 3.75 & 4.0 & Very Valid \\
\hline
\end{tabular}

Based on the data in table 5 above, it shows that the total validity value of the text instrument learning outcomes of the development of metacognitive abilities of PGSD students through the character-based $4 \mathrm{C}$ learning model is 3.75. Based on the existing validity criteria, this value is included in the very valid category because it is at $3,6 \leq p \leq$ 4. In addition, in the aspect component of the assessment of the learning outcome text instrument, the time aspect is the aspect that has the highest validity criteria, namely $4.0 . \bar{x}$

\section{d. Student Response Questionnaire}

After the student response questionnaire has been completed, the researcher validates that questionnaire by several experts to see its level of validity. The average value of each aspect of the assessment on the student response questionnaire can be seen in table 6 :
Table 6. Average student response questionnaire validation results

\begin{tabular}{ccccc}
\hline No. & Assessment Aspects & $\overline{\mathbf{x}}$ & $\mathbf{( A i )}$ & Information \\
\hline 1. & $\begin{array}{c}\text { Learning tool } \\
\text { components }\end{array}$ & 3.68 & 3,7 & Very Valid \\
\hline 2. & Novelty & 3.68 & 3.8 & Very Valid \\
\hline 3. & $\begin{array}{c}\text { Understanding the } \\
\text { contents of model books } \\
\text { and teaching materials }\end{array}$ & 3.68 & 3,3 & Very Valid \\
\hline 4. & $\begin{array}{c}\text { Implementation of } \\
\text { learning }\end{array}$ & 3.68 & 3,9 & Very Valid \\
\hline
\end{tabular}

Based on the data presented in table 6 above, it shows that the total mean value of the validity of the student response questionnaire results is 3.68 . Based on the validity criteria, the average value is included in the very valid category because it is at $3.6 \leq \mathrm{p} \leq 4$. In addition, the novelty aspect of the student response questionnaire component has the highest validity criteria, namely 3.8. Besides providing an assessment, the validator also provides suggestions and comments for revisions to the student response questionnaire. However, the two validators did not provide any suggestions or ministries, so that the general assessment for the student response questionnaire could be applied without revision.

\section{e. Lecturer Response Questionnaire}

The last product of this research to be validated is a lecturer response questionnaire. The average validation results for each aspect of the assessment on the questionnaire can be seen in the table below:

Table 7. Average validation results questionnaire for lecturer responses

\begin{tabular}{ccccc}
\hline No & Assessment Aspects & $\overline{\mathbf{x}}$ & $\mathbf{( A i )}$ & Information \\
\hline 1. & Learning Media & 3.66 & 3,6 & Very Valid \\
\hline 2. & Serving Feasibility & 3.66 & 3.5 & Very Valid \\
\hline 3. & Language Eligibility & 3.66 & 3.5 & Very Valid \\
\hline 4. & Learning Assessment & 3.66 & 4.0 & Very Valid \\
\hline
\end{tabular}

Based on the data in table 7 above, it shows that the total mean value of the validity of the lecturer response questionnaire results is 3.66 . Based on the existing validity criteria, the value is included in the very valid category because it is at $3.6 \leq p \leq 4$. In the component of lecturer's response rate, the aspect of learning assessment has high validity criteria, namely 4.0. The results of the validation were corroborated by the absence of criticism or suggestions for improvements to the components of the assessment of the lecturer response questionnaire from the two validators. This shows that the lecturer response questionnaire sheet can be applied without revision.

\section{2) Practicality Test Results}

The data from the lecturer response questionnaire were then analyzed to determine the average value in each aspect. After that, the researchers determined the overall average value. The results of the student response questionnaire 
analysis showed that the average value of the component aspects of the learning tools was 3.7, the presentation feasibility aspect was 3.8 , the language feasibility aspect was 3.3 , and the learning assessment aspect was 3.8. Overall, the average value of the lecturers' response was 3.61 and included in the very practical category.

Table 8. Results of the lecturer response questionnaire analysis

\begin{tabular}{cccc}
\hline No. & Assessment Aspects & $\overline{\mathbf{x}}$ & (Ai) \\
\hline 1. & Learning device components & 3.61 & 3.7 \\
\hline 2. & Presentation feasibility aspect & 3.61 & 3.8 \\
\hline 3. & Aspects of language eligibility & 3.61 & 3.3 \\
\hline 4. & The assessment aspect of learning & 3.61 & 3.8 \\
\hline
\end{tabular}

Furthermore, student response questionnaires were also analyzed to determine the level of practicality of this character-based 4C learning model. In full, the results of the student response questionnaire analysis can be seen in the following table.

Table 9. Results of student response questionnaire analysis

\begin{tabular}{cccc}
\hline No. & Assessment Aspects & $\overline{\mathbf{x}}$ & $\mathbf{( A i )}$ \\
\hline 1. & Learning device components & 3.64 & 3.5 \\
\hline 2. & The novelty in components & 3.64 & 3.6 \\
\hline 3. & $\begin{array}{c}\text { Understanding the contents of model books } \\
\text { and teaching materials }\end{array}$ & 3.64 & 3.7 \\
\hline 4. & Metacognitive abilities & 3.64 & 3.8 \\
\hline
\end{tabular}

Table 9 above shows that the student response to the character-based $4 \mathrm{C}$ learning model is very positive. The average value for the component aspects of the learning device was 3.5 , the novelty in the components was 3.6 , the understanding of the contents of the model book and teaching materials was 3.7 , and the metacognitive ability aspect was 3.8. The mean total score of the student's response is 3.64 and is categorized as very practical because it is in the range $3.60 \leq \mathrm{M} \leq 4.0$.

\section{3) Effectiveness test results}

Before further testing, the students' pretest and posttest data were tested to see whether the data was normal or not.Data is called normally distributed if it meets the criteria for normality, namely if Sig. > A (0.05) and not normally distributed if Sig. $<$ A (0.05). Table 10 below is the result of processing with the help of SPSS in testing the normality of the pretest and posttest data.

Table 10. Tests of Normality

\begin{tabular}{|l|c|c|c|c|c|c|}
\hline \multirow{2}{*}{} & \multicolumn{2}{|c|}{ Kolmogorov-Smirnova } & \multicolumn{3}{c|}{ Shapiro-Wilk } \\
\cline { 2 - 7 } & Statistics & Df & Sig. & Statistics & df & Sig. \\
\hline Pretest & .196 & 16 & .102 & .939 & 16 & .332 \\
\hline Posttest & .197 & 16 & .098 & .870 & 16 & .027 \\
\hline
\end{tabular}

Based on table 10 above, it shows that the pretest normality test results obtained Sig. $=0.332>0.05$, while the results of the posttest normality test obtained the Sig. = $0.027>0.05$. This shows that the pretest and posttest data meet the normality test criteria so that it can be concluded that the metacognitive ability test results through learning the basic concepts of PPKn, STKIP Andi Matappa PGSD student, Pangkep Regency are normally distributed.

Table 11. Paired Samples Statistics

\begin{tabular}{cccccc}
\hline & & Mean & N & Std. Deviation & Std. Mean Error \\
\hline \multirow{2}{*}{ Pair 1 } & Pretest & 2,656 & 16 & .1209 & .0302 \\
& Posttest & 3,325 & 16 & .1065 & .0266 \\
\hline
\end{tabular}

Based on Table 11 above, a summary of the descriptive statistical results of the two samples studied is shown, namely the pretest and posttest values. For the pretest score, it was obtained that the average student metacognitive ability or mean was 2,656 , while for the posttest score, the average value of students' metacognitive ability was 3,325. For the value of Std. Deviation at pretest was 0.1209 and posttest was 0.1065 . Finally, Std. Mean error for the pretest is 0.0302 and for the posttest is 0.0266 . Because the average value of metacognitive abilities at pretest was $2.656<$ posttest 3.325 , it means that descriptively there is a difference in the average metacognitive ability between pretest and posttest results.

\section{Discussion}

Implementation character-based 4C learning model packaged in the form of learning book products that were tested on PGSD STKIP Andi Matappa students, Pangkep Regency[46]. The results of this limited trial in an operational model for the development of students' metacognitive abilities through the character-based $4 \mathrm{C}$ learning model [47], [48]. The validator's assessment of the development product which includes all the tools that have been presented, is declared valid as a whole so that it is suitable for use and development. In other words, the product of metacognitive development fulfills the feasibility aspect [17], [49].

In terms of validity, it shows that the assessment of the two validators of students' metacognitive development products through character-based 4C learning model which includes all the tools that have been presented, can be declared valid as a whole so that it is declared fit for use and developed in STKIP Andi Matappa Pangkep Regency [50].The validation process usually assesses various aspects of the product, including aspects of language, content, and presentation. However, some experts assess several aspects of the validation test, such as adequacy, coherence, suitability and usability [51]. The product can be proven valid if the experts believe that the development product can measure the skills specified in the measured domain [52], [53].

In terms of practicality, then something is said to be 
practical if the experts (validators) state that the character-based $4 \mathrm{C}$ learning model can be used without revision or slight revision [54]. Based on the results of the practicality assessment in general, the results show that the character-based 4C learning model fulfills the practical aspects so that this learning model is feasible to use. The practicality test for development student metacognitive through character-based $4 \mathrm{C}$ learning model measurements can be made by responding to students and lecturers with a questionnaire or questionnaire [40].The product is declared practical if it meets two criteria, namely the teacher's assessment states that the model can be applied with minor revisions and the model can be implemented because it is in accordance with the applicable curriculum, time allocation, and school conditions [55]. In addition, a product is said to be practical if lecturers and students as users have an interest and give positive responses to the product [56]-[58]

Results of lecturer responses obtained the average value of total lecturer activity from each aspect of 3.61 with a percentage of $62.77 \%$. With this percentage of results, it means that the activities of the lecturer towards the $4 \mathrm{C}$ learning model can be said to be active [59], [19]. Therefore, the two lecturers agreed that the character-based 4C learning model improved students' metacognitive abilities. While the average value of total student activity based on the results of student responses distributed was 3.64 with the percentage of activity $63.31 \%$ [60]. With the percentage of results obtained, it shows that students in providing an assessment of the $4 \mathrm{C}$ learning model can be said to be active.Based on these two results, it shows that both student response and dose in developing metacognitive abilities through character-based 4Cs learning modelis indispensable [61].

In addition to being valid and practical, the character-based $4 \mathrm{C}$ learning model is also effective in improving students' metacognitive abilities. This can be seen from the results of the t-test using the help of the SPSS application which states that there is an increase in learning outcomes at posttest scores when compared to pretest scores. In line with these findings, Hamdan [62] states that effectiveness can be seen from three aspects, namely: (a) the achievement of goals in accordance with the set priorities, (b) conformity to needs, and (c) have a positive effect on increasing knowledge, attitudes and behavior.

\section{Conclusions}

This research is a develop phase in the 4D model for this type of research and development. The develop phase consists of three testing activities for the product development results, namely testing the validity, practicality, and effectiveness. The results of this research indicate that the products developed are valid, practical, and effective. The validity trial was carried out on 2 experts who assessed the feasibility of the product and based on the analysis of the assessment they provided proved that the product was valid. Second, the practicality trial of this learning model was carried out on 2 lecturers as respondents. The results of the two practitioners' assessment indicate that the character-based $4 \mathrm{C}$ learning model is considered practical. Finally, the effectiveness test was carried out by testing limited to one class by conducting pretest and posttest.

\section{REFERENCES}

[1] L. Greenstein, Assessing 21st Century Skills: A Guide Evaluating Mastery and Authentic Learning. Thousand Oaks, CA, 2002.

[2] H. Kanematsu and M. D. Barry, "STEM and ICT education in Inteligent Environments," Springer International Publishing, vol. 91, 2016. https://doi.org/10.1007/978-3-31 9-19234-5

[3] Cruickshank and R. Donal, The Act of Teaching. Jakarta, Indonesia: Salemba Humanika, 2014.

[4] N. Suryani, "Implementation of Collaborative Learning Models to Improve Students' Social Skills," Learning Scientific Magazine., vol. 8, no. 2, 2010. https://journal.uny.ac.id/index.php/mip/article/viewFile/365 $/ 3127$

[5] M. Hosnan, Scientific and Contextual Approaches in 21st Century Learning. Jakarta, Indonesia: Indonesia Ghalia Publisher, 2016.

[6] Association of Thai Professionals in America and Canada, "National STEM Education Center, Science, Technology, Engineering, and Mathematics (STEM) Education in The US and Its Translational Approaches to Thailand," 2015. [Online]. Available:http://www.atpac.org/wp-content/uploa ds/2015/08/STEM-Report-Final-Final-Revision.pdf. [Accessed: 25-Dec-2020].

[7] F. Banks, "Technological Literacy in a Developing World Context," in Positioning Technology Education in The Curriculum, M. J. De Vries, Ed. Rotterdam: Sense Publisher, 2011, pp. 219-225.

[8] M. Stohlmann, T. Moore, and G. Roehrig, "Considerations for Teaching Integrated STEM Education," Journal Pre-college Engineering Education Research, vol. 2, no. 1, pp. 28-34, 2011.

[9] T. R. Kelley and J. G. Knowles, "A Conceptual Framework for Integrated STEM Education," International Journal of STEM Education, vol. 3, no. 1, 2016. https://doi.org/10.1186/s40594-016-0046-Z

[10] T. Trianto, Model Pembelajaran Terpadu dalam Teori dan Praktik. Jakarta, Indonesia: Prestasi Pustaka, 2010.

[11] M. P. Trianto, Mendesain Model Pembelajaran Inovatif-progresif. Jakarta: Kencana Prenada Media Group, 2009.

[12] S. Sagala, Konsep dan Makna Pembelajaran. Bandung, Indonesia: Alfabeta, 2010. 
[13] B. Joyce, M. Weil, and Emily Calhoun, Models of Teaching, Delapan. Yogyakarta: Pustaka Pelajar, 2011.

[14] A. Susanto, Teori Belajar dan Pembelajaran di Sekolah. Jakarta, Indonesia: Kencana Prenada Media Group, 2013.

[15] O. Hamalik, Proses Belajar Mengajar. Jakarta, Indonesia: Bumi Aksara, 2004.

[16] S. Sugiyanto, Model Pembelajaran Inovatif. Jakarta, Indonesia: Heksan, 2011.

[17] R. L. Tobing, A. Setia, and H. Hinduan, "Special Methodic Teaching Teaching Models for Elementary School Natural Science Education,” Jakarta, Indonesia, 1990.

[18] S. Zubaidah, "Get to Know 4C: Learning and Innovation Skills to Face of The Industrial Revolution 4.0," in The 2nd Science Education National Conference Seminar at Trunojoyo Madura University, 2018, pp. 1-18.

[19] A. Nurjanah, "The Effectiveness of Metacognitive Strategies in Mathematics Learning in Terms of The Mathematics Problem Solving Ability of Class VII Students of SMP Negeri 3 Sleman," Universitas Negeri Yogyakarta, 2015 .

[20] P. Eggen and D. Kauchak, Strategi dan Model Pembelajaran: Mengajarkan Konten dan Keterampilan Berpikir Kritis. Jakarta: Indeks, 2012.

[21] T. Tayeb, "Analisis dan Manfaat Model Pembelajaran," Auladuna: Jurnal Pendidikan Dasar Islam, vol. 4, no. 2, pp. 48-55, 2017.

[22] Y. P. Pateliya, "An Introduction to Modern Models of Teaching," International Journal of Research Education, vol. 2, no. 2, pp. 125-129, 2013.

[23] S. Suyono and H. Hariyanto, Belajar dan Pembelajaran. Bandung: Remaja Rosdakarya, 2011.

[24] C. R. Kilbane and N. B. Milman, Teaching Models: Design Instructionfor 21st Century Learners. New Jersey: Perason Education, 2014.

[25] WEF (World Economic Forum), "New Vision for Education: Fostering Social and Emotional Learning through Technology," Geneva Switzerland, 2016.

[26] R. V. Sanavi and S. Tarighat, "Critical Thinking and Speaking Proficiency: A Mixed-method Study," Theory and Practice in Language Studies, vol. 4, no. 1, pp. 79-87, 2014. https://doi.org/10.4304/tpls.4.1.79-87

[27] T. Turabik and F. Gün, "The Relationship between Teachers' Democratic Classroom Management Attitudes and Students' Critical Thinking Dispositions," Journal of Educational and Training Studies, vol. 4, no. 12, pp. 45-57, 2016. https://doi.org/10.11114/jets.v4i12.1901

[28] T. D. C. Nakano and S. M. Wechsler, "Creativity and Innovation: Skills for the 21st Century," Estudos de Psicologia, vol. 35, no. 3, pp. 237-246, 2018. https://doi.org/10.1590/1982-02752018000300002

[29] B. Beyer, Practical Strategies for Teaching of Thinking. Boston: Allynannd Bacon Inc, 1987.

[30] L. Greenstein, Assesing Skill 21st Century. A Guide to Evaluating Mastery and Authentic Learning. New York:
Crowin A SAGE Company, 2012.

[31] M. Bialik and C. Fadel, "Skills for the 21: What should Students Learn?," Boston, 2015.

[32] K. Ülger, "The Relationship between Creative Thinking and Critical Thinking Skills of Students," Hacettepe University Journal of Education, vol. 31, no. 4, 2016.

[33] Z. H. Iksan et al., "Communication Skills among University Students," Procedia -Social Behavioral Science., vol. 59, pp. 71-76, 2012. https://doi.org/10.1016/j.sbspro.2 012.09.247

[34] H. Z. Matin, G. Jandaghi, F. H. Karimi, and A. Hamidizadeh, "Relationship between Interpersonal Communication Skills and Organizational Commitment (Case Study: Jahad Keshavarzi and University of Qom, Iran)," Eur. J. Soc. Sci., vol. 13, no. 3, pp. 387-398, 2010.

[35] H. Helaluddin and A. Fransori, "Integrasi The Four CS dalam Pembelajaran Bahasa," Eduhumaniora: Jurnal Pendidikan Dasar, vol. 11, no. 2, pp. 95-106, 2019.

[36] NEA, "Preparing 21st Century Students for a Global society," National Education Association, 2015. [Online]. Available:

http://www.nea.org/assets/docs/A-Guided-to-Four-Cs.pdf. [Accessed: 16-Apr-2019].

[37] S. Jaleel and P. Premachandran, "A Study on the Metacognitive Awareness of Secondary School Students," Universal Journal of Educational Research, vol. 4, no. 1, pp. 165-172, 2016. https:10.13189/ujer.2016.040121

[38] Y. Coşkun, "A Study on Metacognitive Thinking Skills of University Students," Journal of Education and Training Studies, vol. 6, no. 3, pp. 38-46, 2018. https://doi.org/10.11114/jets.v6i3.2931

[39] S. A. Tachie, "Meta-cognitive Skills and Strategies Application: How this Helps Learners in Mathematics Problem-solving," Eurasia Journal of Mathematics, Science and Technology Eduation, vol. 15, no. 5, pp. 1-12, 2019. https://doi.org/10.29333/ejmste/105364

[40] S. Thiagarajan, D. S. Semmel, and M. I. Semmel, Instructional Development for Training Teachers of Exceptional Children. Blomington Indiana: Indiana University, 1974.

[41] T. Supartini, I. T. J. Weismann, H. Wijaya, and H. Helaluddin, "Development of Learning Methods through Songs and Movements to Improve Children's Cognitive and Psychomotor Aspects," European Journal of Educational Research, vol. 9, no. 4, pp. 1615-1633, 2020. https://doi.org/10.12973/eu-jer.9.4.1615

[42] H. Hasmawaty, H. Syam, and A. Saman, "Validity, Practicality, and Effectiveness: The Last Step in Development of Entrepreneurship Education Based Role-Playing for Kindergarten," Universal Journal of Educational Research, vol. 8, no. 12, pp. 8092-8101, 2020. https://doi.org/10.13189/ujer.2020.082611

[43] M. Jafarigohar, F. Hemmati, A. Rouhi, and H. Divsar, "Instructors'Attitudes towards The Reflection of Critical Thinking in Course Syllabi: Evidence from An Expanding Circle," Theory \& Practice in Language Studies, vol. 6, no. 1, 2016. https://doi.org/10.17507/tpls.0601.08 
[44] T. G. Ratumanan and T. Laurens, Penilaian Hasil Belajar pada Tingkat Satuan Pendidikan. Surabaya: Unesa University Press, 2011.

[45] T. Tirtamayasari, A. W. Jufri, and A. Harjono, "NValiditas Perangkat Pembelajaran IPA Berbasis Masalah Bermuatan Karakter," Jurnal Pendidikan Fisika dan Teknologi, vol. 5, no. 2, pp. 221-226, 2019. https://doi.org/ 10.29302/jpft.v5i2.1419

[46] M. Muhajir, "Inquiry Strategy Learning to Improve Critical Thinking Skills of Students of The Pancasila and Citizenship Education Study Program," in Proceeding of The III National Citizenship Conference, 2017.

[47] P. Setyosari, Educational Research \& Development Methods. Jakarta, Indonesia: Prenada Media Publisher, 2016.

[48] A. Roberts, "A Justification for STEM Education," Technology and Engineering Teacher, vol. LXXIV, no. 8, pp. 1-5, 2012.

[49] L. G. Snyder and M. J. Snyder, "Teaching Critical Thinking and Problem Solving Skills," The Delta Pi Epsilon Journal, vol. L, no. 2, pp. 90-99, 2008.

[50] K. Sihotang, Critical Thinking Life Skills in The Digital Era. Yogyakarta, Indonesia: PT Kanisius, 2019.

[51] D. V. Rogayan Jr. and L. F. Dollete, "Development and Validation of Physical Science Workbook for Senior High School," Science Educaton International, vol. 30, no. 4, pp. 84-290, 2019. https://doi.org/10.33828/ sei.v30.i4.5

[52] S. Ramadhan, D. Mardapi, Z. K. Prasetyo, and H. B. Utomo, "Development of An Instrument to Measure The Higher Order Thinking Skill in Physics," European Journal of Educational Research, vol. 8, no. 3, pp. 743-751, 2019. https://doi.org/10.12973/eu-jer.8.3.743

[53] N. Kholis, B. Kartowagiran, and D. Mardapi, "Development and Validation of An Instrument to Measure A Performance of Vocational High School," European
Journal of Educational Research, vol. 9, no. 3, pp. 955-966, 2020. https://doi.org/10.12973/eu-jer.9.3.955

[54] A. Suprijono, Cooperative Learning (PAIKEM Application Theory). Yogyakarta, Indonesia: Pustaka Pelajar, 2011.

[55] A. Jaedun, V. L. Hariyanto, and N. E. Raharjo, "Pengembangan Model Pembelajaran Produktif Bermuatan Kewirausahaan," Jurnal Kependidikan, vol. 1, no. 1, pp. 125-138, 2017.

[56] M. K. Mustami, S. Syamsudduha, S. Safei, and M. I. Ismail, "Validity, Practicality, and Wffwctiveness Development of Biology Textbooks Integrated with Augmented Reality on High School Students," International Journal Technology Enhanced Learning, vol. 11, no. 2, pp. 187-200, 2019.

[57] Y. Hala, S. Saenab, and S. Kasim, "Pengembangan Perangkat Pembelajaran Bilogi Berbasis Pendekatan Saintifik pada Konsep Ekosistem bagi Siswa Sekolah Menengah Pertama," Journal of Education and Science Technology, vol. 1, no. 3, pp. 85-96, 2015.

[58] A. Yazid, Kevalidan, Kepraktisan, dan Efek Potensial Suatu Bahan Ajar. Palembang: Pascasarjana Universitas Sriwijaya, 2011.

[59] A. Woolfolk, "Instructional Psychology," in Active Learning, H. Prajitno and S. M. Soetjipto, Eds. Yogyakarta, Indonesia: Pustaka Pelajar, 2008.

[60] K. P. Zuhdan, "Development of Integrated Science Learning Tools to Improve Cognitive, Process Skills, Creativity and Applying Scientific Concepts of Junior High School Students," Thesis. Postgraduate of Universitas Negeri Yogyakarta, 2011.

[61] S. Sugiyono, Educational Research Methods. Bandung, Indonesia: Alfabeta, 2016.

[62] H. Hamdan, "Model Pengembangan Kreativitas dan Inovasi dalam Membentuk Entreperneur di Era Ekonomi Digital," Jurnal Manajemen \& Kewirausahaan, vol. 7, no. 1, pp. 59-68, 2019. 